\title{
ORGANIZATIONAL FORM AND \\ INSURANCE COMPANY PERFORMANCE: \\ STOCKS VERSUS MUTUALS
}

\author{
Patricia Born \\ William M. Gentry \\ W. Kip Viscusi \\ Richard J. Zeckhauser
}

Working Paper 5246

\section{NATIONAL BUREAU OF ECONOMIC RESEARCH 1050 Massachusetts Avenue \\ Cambridge, MA 02138 \\ September 1995}

We are grateful to Miriam Aoins, Georges Dionne, Dwight Jaffee, Deborah Lucas, Sean Mooney, and participants at the Franco-American Seminar on Risk and Insurance and an NBER conference on property-casualty insurance for helpful comments. Views and opinions presented in this paper are solely those of the authors and do not reflect positions of any organization with which they are affiliated. This paper is part of NBER's research programs in Corporate Finance and Industrial Organization.

() 1995 by Patricia Born, William M. Gentry, W. Kip Viscusi and Richard J. Zeckhauser. All rights reserved. Short sections of text, not to exceed two paragraphs, may be quoted without explicit permission provided that full credit, including $($ notice, is given to the source. 


\title{
ORGANIZATIONAL FORM AND \\ INSURANCE COMPANY PERFORMANCE: \\ STOCKS VERSUS MUTUALS
}

\begin{abstract}
One unusual feature of the U.S. property-casualty insurance industry is the coexistence of stock and mutual companies. This paper explores the performance of these forms in the industry through a dynamic assessment of how mutual and stock insurance companies respond to differences in their underwriting environment. Agency theories suggest that the stock company may be more "opportunistic" and less obligated to their insureds than mutuals. This article assesses the responses by stock and mutual firms to changes in the underwriting environment from 1984 to 1991, using measures of individual firms' performance, by state and by line, in eight different lines of insurance. Stock companies are more likely than mutuals to reduce their business in unprofitable situations, and have higher losses than mutuals for a given amount of premiums.
\end{abstract}

Patricia Born

American Medical Association

Center for Health Policy Research

515 North State Street

Chicago, IL 60610

W. Kip Viscusi

Department of Economics

Duke University

Durham, NC 27706
William M. Gentry

Graduate School of Business

Columbia University

608 Uris Hall

New York, NY 10027

and NBER

Richard J. Zeckhauser

John F. Kennedy School of Government

Harvard University

79 JFK Street

Cambridge, MA 02138

and NBER 


\section{Introduction}

One unusual feature of the U.S. property-casualty insurance industry is the coexistence of for-profit stock companies and non-profit mutual companies. For-profit enterprises dominate almost all other sectors of the financial services industry, 'while cooperatives play a role in some local markets but are in general a minor organizational form. Stock insurance companies are similar to corporations in other industries: shareholders provide capital to the company, own the residual claims to the company's profits, and elect the board of directors to oversee its management. Mutual insurance companies, by contrast, are corporations that are owned by their customers: the policyholders provide capital through premiums, may receive dividends (in addition to insurance) from the firm, and elect the board of directors to manage the business. In 1991 , stock companies accounted for $67 \%$ of overall property-casualty premiums in the U.S., compared to $25 \%$ for mutual companies. ${ }^{2}$ However, the relative importance of these two forms varies across lines of insurance. For example, stock companies earned $71 \%$ of commercial multiple peril premiums but only $36 \%$ of homeowners multiple peril premiums.

Understanding the differences in how mutual and stock insurance companies respond to differences in their underwriting environment should illuminate their distribution in the property-casualty insurance market. More importantly a better understanding of the competitive responses of insurance firms may help in designing insurance regulations, such as, rules aimed at protecting consumers. Consumer protection regulation may have more influence on stock companies than on mutuals, 
given the inherent incentives facing mutual managers to take consumer welfare into account.

Insurance availability and affordability are both policy concerns, as evidenced by government's many regulations of the insurance market. Since the insurance industry has multiple organizational forms, one must understand the likely response of each significant form to predict the industry's overall response to any change in the environment, just as one must pay attention to the grazing habits of multiple animal species to predict how the grass on the Serengeti will respond to a drougnt. Mutual companies may be inherently more interested in making insurance available and affordable, since their policyholders are also owners. They may be more reluctant to exit a market in the face of costly new regulations or a jump in claims that is expected to persist. Stock companies may be quicker to provide insurance services in new lines that have the potential for profitability and growth.

Prevailing economic theories of organizations are based on the hypothesis that a particular form will prevail in an industry if it offers the most effective solution to the industry's particular agency problems. ${ }^{3}$ The form may be chosen consciously, or it may evolve in response to economic pressures affecting survival and growth; the most efficient form eventually prevails. For example, virtually all institutions of higher education are not-for-profit, whereas virtually all restaurants are for-profit organizations.

1 The co-existence of stock and mutual companies in the property-casualty insurance industry suggests that at least one of three hypotheses is true: the two organizational forms have competing advantages; the market may be rich enough that 
different organizational forms can survive in different niches: and the market may not have reached its final equilibrium (or perhaps history may influence the equilibrium).

While stock companies have convenient access to well-developed capital markets, they suffer from a conflict of interest between the shareholders and policyholders; managers of a stock company who act in the best interest of the shareholders might take some opportunities to make profits at the expense of the policyholders. As an extreme example, consider a stock company that is nearly insolvent. Its managers might choose to invest the firm's capital in assets that pay a high return, in part because of significant risk, rather than insure against a low probability but catastrophic event. If nothing untoward happens, the shareholders will reap the profits. However, if the assets collapse or the catastrophic event occurs, it is the policyholders who suffer most from the firm's insolvency. ${ }^{4}$ To lose their monetary claims precisely when insurance was to pay for the costs of coping with a catastrophe is doubly disastrous; it is at such times that the marginal utility of money is highest. The recent experience of Lloyds of London, whereby some names (the general partners) lost vast amounts and were even thrust into bankruptcy, suggests that insolvency risks are not trivial in the insurance arena. There is considerable debate in the United States whether the insurance industry could weather the predicted catastrophic earthquake in California, the so called "big one."

Theoretically, the mutual form of organization eliminates managerial "opportunism" by merging the identity of the policyholders and the residual claimants. ${ }^{5}$ The managers of a mutual do not feel a tension between serving the owners and 
serving the customers: the customers are the owners. Some insurance researchers have hypothesized that mutuals are more efficient at risk sharing since they combine policy and equity claims in a single package, which is a more efficient arrangement for risks that are not easily diversified. While the mutual form of organization may reduce this agency cost, it has distinctive costs of its own. First, mutual companies cannot raise capital from equity markets. Second, the managers of mutual companies are not disciplined by the stock market and the market for corporate control to control costs and otherwise achieve efficiency. Third. the diffuse ownership of mutuals. and the inherent inability of individual policyholders to acquire significant influence. may make it difficult to monitor managerial performance. Pound and Zeckhauser (1990) show that large shareholders play a significant role within corporations in monitoring performance, promoting, for example, a long-term orientation among managers. If policyholders have little control over mutuals' of the managers, then managers may be more likely to act in their own best interest rather than on behalf of the policyholders. For example, mutual firm managers might dissipate the insureds' surplus through expenditures yielding personal benefits. ${ }^{6}$ Unlike nonprofit organizations in many other industries, mutual insurance companies do not enjoy tax-favored status; they are taxed as corporations, and are subject to the same premium taxes as stock companies. Mutuals in other countries, such as France, do receive favorable tax treatment.

There are several kinds of mutual forms in the U.S. insurance industry. In the pure assessment mutual, policyholders pay nothing when they join, but pay their assessed share of any loss after it has occurred. This form is not wide-spread 
because it is difficult to collect. A second form is a mutual that combines the advance premiums with assessable policies. These mutuals return the surplus to the policyholders as dividends. The mutual can levy an additional assessment, which is typically limited to an amount such as the level of the advance premium whenever the additional levy is limited by the bylaws or state law. The third and most prevalent mutual form, which is used by all of the larger U.S. mutuals, is the advance premium non-assessable mutual. These mutuals collect premiums in advance and return the surplus as dividends, but do not levy additional assessments for losses. Regulations permit such mutuals to operate once they demonstrate that they have adequate financial strength to withstand foreseeable losses.

In many respects, mutuals function similarly to stock companies. They collect and invest premiums and pay any shortial from the accumulated surplus. Unlike stock companies, however, the premium is neither fixed nor definite; any excess over cost may be returned as dividends. Policyholders theoretically control the company, serving as implicit shareholders, but they actually exercise less control. Policyhoiders have a weaker incentive than do shareholders to replace management by purchasing a controlling interest since they would have to undertake a proxy fight and would not capture any increases in surplus, such as those due to cost savings.

Previous empirical research on organizational form in the insurance industry has examined static questions, such as how mutual and stock companies differ. Mayers and Smith (1988) examine the geographic and line-of-business concentration of different organizational forms and test the hypothesis that mutual companies will 
serve more concentrated regions or types of business. Several conclusions emerge. First, stock companies serve broader geographic areas than mutual companies; this is consistent with the hypothesis that for-profit organizations are better able to control agency costs particularly when operating from a distance. ${ }^{7}$ Second, mutual companies and stock companies are about as likely to concentrate their activities in a few lines of business. Third, mutuals are relatively more important in some insurance lines, but Mayers and Smith conclude that it is difficult to see why mutuals specialize in particular lines. Lamm-Tennant and Starks (1993) explore the hypothesis that stock companies bear more risk than mutual firms. Their measure of a firm's risk is the variance of the firm's annual loss ratio from 1980 to 1987 . Using this measure, they find that stock companies do bear more risk than mutuals.

This paper explores how organizational form affects a firm's responses to different situations. If stock companies are more "opportunistic" and less obligated to their insureds than mutuals, then they will respond more quickly to changes in regulation or the distribution of claims. For example, consider a hypothetical price cap that reduces the profitability of writing homeowners' insurance in Massachusetts. The shareholders of a stock company might want the company to reduce its homeowners business in that state, just as a supermarket would stop selling products on which it expects to lose money. However, if a mutual firm reduces its business, the big losers will be policyholders, the supposed residual claimants and owners of the firm. ${ }^{8}$ Even without changes in government policy, stock companies might give less weight to the interests of policyholders in changing premiums or quantities in response to changes 
in the market rewards.

Exploring such dynamic questions requires an assessment over time. One way to evaluate the difference in behaviors between stocks and mutuals is to analyze firms' reactions to their past performance in a line, working on the hypothesis that there is some persistence in performance. For example, if a firm was unprofitable in writing medical malpractice insurance last year, will it raise premiums, exit the market, or do nothing? The answer may depend on the firm's loyalty to the interests of its policyholders. It may also depend on the firm's profitability in other areas. assuming that it is costly, unlikely, or impossible for the firm to secure capital from its policyhoiders or shareholders. That is, a substantially lesser response would be expected if the firm was unprofitable in every line last year, than if this line was the sole "loser" for the firm. Finally, the firm's sensitivity to whether a particular line is profitable may depend on the scale of the firm's operations. Big national firms can absorb losses better than small, geographically concentrated firms, so less of a response may be necessary. By comparing the current year's performance to the previous year's. we evaluate the relative influence of such factors on the behavior of stock and mutual companies. $^{9}$

The rest of this paper is organized as follows. Section II provides background information on the relative importance and performance of stock and mutual insurers in the eight lines of business that we study. Section III discusses possible responses by stock and mutual firms to the underwriting environment: changing the premiums they charge, or the quantity of insurance they write, or entering or exiting particular 
markets. Section IV presents our empirical methodology and results on changes in underwriting performance and premiums by organizational form. Section $V$ summarizes our findings.

\section{Performance and Size of Stocks and Mutuals}

In the early nineteenth century, the property-casualty insurance industry was dominated by stock companies that were reluctant to negotiate rates for individual policyholders. ${ }^{0}$ In response to what they felt were uniair prices. regional industry groups, such as textile mills, started mutual insurance companies, the first appeared beginning in 1843 . These mutuals were able to offer lower premiums than stock companies for several reasons. First, the mutual form reassured policyholders that they were not paying inappropriately high rates due to the use of crude and unregulated actuarial tables, i.e., it ameliorated monitoring problems. Second, mutuals screened prospective members in an effort to insure only the better risks. Third, they viewed their members as participants in a long-term relationship and offered helpful services; for example, they provided inspections and recommended loss prevention measures. Fourth, the common interests of the mutuals' members may have reduced moral hazard: For example, farmers in a small mutual may have refrained from filing small claims because they realized that their claims would have raised premiums for themselves and their neighbors. There is anecdotal evidence that an ethic against making such claims did develop, and was reinforced because the farmers could monitor and sanction one another. Thus, the insurance industry's problems of 
information monitoring may make the mutual form of organization more advantageous in certain areas.

Some of the regional mutuals began to write personal lines of insurance as the composition of demand changed over time. For example, some farm and fire mutuals formed automobile insurance mutuals. The concentration of mutuals in midwestern states suggests that ideological and regional factors also influenced the development of mutuals. Yet such historical factors do not necessarily explain the survival of the form alongside for-profit firms. As mentioned above, an economic explanation for the coexistence of stock and mutual companies is that their differing approaches to agency problems allow them to prevail in different lines, or perhaps that they confront slightly different circumstances, and hence must solve different problems. Under this hypothesis, one would expect the two organizational forms to behave differently, even though they might be roughly equal competitors in some markets.

To test for behavioral differences between organizational forms, we analyze eight lines of insurance: homeowners' multiple peril, commercial multiple peril, medical malpractice, general liability, personal automobile liability, commercial automobile liability, personal automobile property damage, and commercial automobile property damage. These lines represent the majority of the property-casualty insurance business in the U.S. ${ }^{11}$ Among these lines, stock companies wrote between $36 \%$ and $79 \%$ of industry premiums in 1991 . This set of lines also provides a mixture of personal and commercial insurance lines as well as a combination of lines that were adversely affected by the mid-1980s' liability insurance crisis and those that remained 
relatively stable.

Table 1 compares various characteristics of stock and mutual firms by line for 1991. These data are from the National Association of Insurance Commissioners' (NAIC) records of property and casualty insurance companies' annual financial statements. All firms writing insurance for each line reported its insurance information to the state insurance commissioners in response to regulatory requirements. Three conclusions emerge. First, stock firms collect greater total premiums than mutuals in all of the lines except homeowners' multiple peril. Outside of homeowners. mutuals are most important in personal automobile insurance, for which they write more than one-third of all premiums. Second, in all of the lines except homeowners, considerably more stock companies write insurance than mutuals, by a ratio that is generally larger than their ratio of premiums. Third, a comparison of the mean and median firm premiums by line suggests no clear pattern in terms of whether of one organizational form is generally larger or smaller than the other. ${ }^{12}$ This is important; it suggests that organizational form is not just a proxy for size. Stock firms have the growth advantage of being able to go to the capital markets and issue equity.

Table 2 presents changes in the relative importance of stock and mutual firms from 1984 to 1991 . In six of the eight lines, the relative importance of stocks and mutuals remains almost constant; the exceptions are general liability and medical malpractice. These two lines were most affected by the expansion of tort liability in the mid-1980s. In these lines, the percent of premiums earned by stock companies falls precipitously; those collected by mutuals do not rise proportionately. The decreased 
role of stock companies in these markets should not be regarded as a sign of organizational demise; rather responsive profit-making enterprises might well decrease their operations in markets that have become unprofitable. During this period, mutuals wrote the same fraction of total malpractice insurance, and significantly decreased their fraction of general liability insurance. Risk retention groups, which emerged when insurance was hard to find, contributed to the relative decline of stocks and mutuals in these areas. ${ }^{13}$ Table 2 does not show that either stocks or mutuals have been driving the other organizational form from the market in any line over the last decade. What did drive both types of firms from these markets, and boistered the potential of risk retention pools, was a dramatic increase in rates due to losses in these areas.

Table 3 reports a summary measure of underwriting profitability, the loss ratio, by line for each organizational form from 1984 to $1991 .^{14}$ The table also reports the weighted standard deviation of the firm-level loss ratios. Figure 1 graphs the timeseries of loss ratios for each line. The loss ratio is the aggregate losses incurred by the organizational form in each line divided by premiums earned less policyholder dividends paid (for mutuals and participating policies of stock companies). This is the principal measure of insurance underwriting profitability, and can be viewed as the inverse of the ex post price of insurance. Higher loss ratios imply that the business was less profitable. These loss ratios are constructed using the premium-weighted mean of the firm-level loss ratios by line.

Figure 1 reinforces the lesson that neither form has a clear advantage over the other. Neither is clearly more profitable than the other, or at least not to an extent that 
can be discerned by visual inspection. However, in the two automobile physical damage lines, mutuals have worse loss ratios than stocks in every year. (We explore the statistical significance of differences in loss ratios across organizational form in our regression analysis below.) The loss ratios for both forms are the most volatile and the highest in general liability and medical malpractice insurance, reflecting the liability crisis of the mid-1980s. Profitability was restored, in part, by the liability reforms of $1985-1987 .^{15}$

In summary, the aggregate and firm-level statistics by organizational form do not reveal striking differences between stock and mutual firms. Thus, the data provide no evidence for such simple hypotheses as "small firms organize as mutuals" or "mutuals have a special advantage in one line of business." However, these aggregate and firm-level statistics cannot confirm whether stock and mutual firms behave differently within each market. To learn this, we analyze the dynamics of firm-level data.

III. Stock and Mutual Company Responses to the Underwriting Environment Different organizational forms smooth risk through different mechanisms. A stock company redistributes risk among policyholders and from individual policyholders to shareholders, who diversify their risk through the equity market. A mutual company distributes risk by pooling the risks of its policyholders. However, since the policyholders are their own residual claimants, they cannot share common their risk with less affected or less risk-averse shareholders. (Some risks can be laid 
off on other companies through reinsurance activities, a practice used by both stock and mutual companies.) The shareholders of stock companies hire managers to maximize the value of the shareholders' claims, while customers come to the company to spread their risks. In contrast, the policyholders of mutual companies hire managers to spread risk among the policyholders by pooling.

Managers of stock companies must deal with conflicting pressures to provide shareholders with profits and policyholders with affordable insurance. By uniting owners and customers, the mutual form mitigates this agency problem. However, policyholders of mutual companies have little incentive to monitor the managers since any residual claims they have are non-transferable, last only as long as their policy is in force, and cannot be magnified by buying more shares or taking control of the company. ${ }^{18}$ If profits on current policies are not distributed immediately, then those who hold policies when the profits are earned do not receive either dividends associated with those profits while they owned the firm nor compensation in the form of a higher share price. In contrast, shareholders' claims on the firm's assets are proportionate to the number of shares they own, are transferable, and are coterminous with the life of the stock company. Hetherington (1991) hypothesizes that these differences undermine the mutuals' ability to mitigate the agency costs associated with the conflict of interest between shareholders and policyholders; thus, managers of mutuals behave like firmly entrenched managers of stock companies.

To the extent that these differences in incentives to monitor managers' behavior (or other attributes of organizational form) affect performance, then stocks and 
mutuals should respond differently to differences in or changes in their underwriting environment. We focus on whether stock and mutual firms respond differentially to a broad measure of profitability in their underwriting environment. Since underwriting profitability varies by line of insurance (see Figure 1) and, possibly, by state of business, we use a relative measure of lagged profitability for the firm in a specific line of business and state of operation. Specifically, we divide the previous year's loss ratio for the firm in an insurance line and state by the overall underwriting loss ratio of all firms operating in the specific line and state. This ratio measures a firm's relative operating environment under the assumption that firm-specific business conditions have some persistence from one year to the next. Since stock and mutual companies face similar contemporaneous shocks to underwriting profitability, differences in how their premiums, losses, and profitability respond to their previous profitability may reveal differences in firm decisions. For example, firms with relatively high loss ratios (low profitability) may want to raise their prices or lower their quantity of business.

Since state governments are responsible for insurance regulation, interstate differences in regulation could also create variation in firms' operating environments, which could be used to explore the differential responses of organizational forms. Broadly speaking, regulatory systems can be classified as either "non-competitive" or "competitive" rate-making regimes. ${ }^{17}$ The common element of the various regimes that would be classified as "non-competitive" is that insurers cannot freely adjust rates without prior approval. In the empirical work, we focus on a state fixed effects formulation so that the role of regulation cannot be distinguished explicitly from other 
state-specific differences. Formulations excluding state fixed effects but including measures of regulatory differences failed to indicate a consistent or significant effect of regulation on the performance of stocks and mutuals. ${ }^{18}$

\section{Empirical Methodology and Results}

The ideal measure of a firm's responses to its environment would be changes in its prices and quantities. ${ }^{19}$ For an insurance policy with a fixed set of contractual terms, it might be possible to construct a time-series of prices: however, policies vary important details, such as the deductible or whether copayments are required, and such details are not made public. Thus, we use firm-level financial data on premiums and losses by year, state, and line of business. Unfortunately, such data do not enable us to separate the price and quantity of insurance issued.

As measures of a firm's responses to its underwriting environment, we use premiums earned (the product of "price" times "quantity"), losses incurred, and firm profitability. We measure firm profitability as its loss ratio in each line of insurance in each state. We use premiums earned to measure the scale of each firm's operations; losses incurred is a second measure of scale. We estimate separate ordinary least squares regressions for each dependent variable for each line of insurance.

We use NAIC data from the annual financial statements for almost all insurance firms in the United States for the years 1984-1991. This data set is the most extensive information available at the firm level, as insurers are required to submit information to the NAIC on a by-line and by-state basis. For each firm in the sample, we know the 
losses incurred and premiums earned by line in each state. The data also specify the firm's organizational form and total assets. Since our specifications include lagged variables, our regressions use data for 1985-1991.

We analyze firm-level data in each state for each line. While we could consolidate our firms into groups to get a more aggregate unit of analysis we use firmlevel data since organizational form is defined at the firm level, and insurance companies often divide their business into different subsidiary firms. Some insurance groups are composed of both mutual and stock firms. The siock firms in these groups are typically privately-held with a mutual firm parent owning most of the shares. These mutual-owned stock companies are an important segment of the industry; in . 1991, they wrote almost one-third of total property-casualty premiums (all lines of business) in the U.S. (as calculated from the NAIC data). One rationale for combining mutuals and stocks within a group is that the managers of the mutual can be given or induced to by shares of the stock subsidiary to provide a form of incentive compensation (see Hetherington, 1991, p. 43).

As discussed by Mayers and Smith (1994), the mutual-owned stock form of organization presents a somewhat different agency problem than either widely-held stock companies or mutuals. These mutual-controlled stocks could behave similarly to their parent mutuals since they often have common directors. Rather than impose that these firms behave like either stocks or mutuals, our empirical specifications allow for three types of firms: stocks that are not owned by mutual parents, mutual-owned stock companies and mutuals. 


\section{Premium Effects}

In using premiums earned as our measure of firm behavior, we estimate the following reduced-form equation, which includes both state- and year-fixed effects: ${ }^{20}$

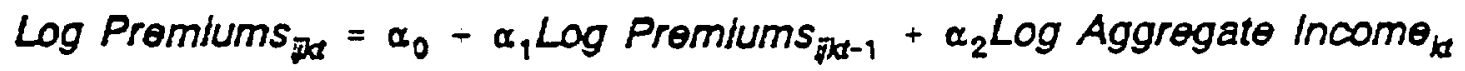

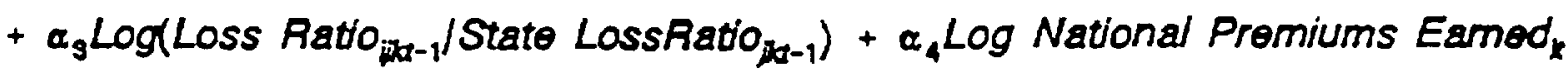

$+a_{5}$ Stock $1+a_{8}$ Mutual-Owned Stock,

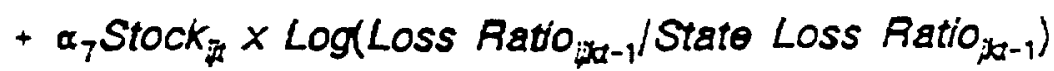

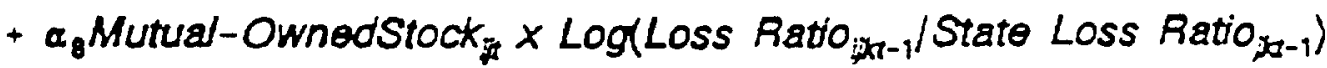

$+\alpha_{9}$ Stock $_{\overline{\bar{x}}} \times \log$ National Promiums Eamod

$+\alpha_{10}$ Mutual-Ownod Stock $\times$ Log National Premiums Eamod

$+\sum_{k} \beta_{k}$ State $_{k}+\sum_{i} \delta_{t} Y_{\theta e a r_{t}}+\epsilon_{\text {Bgtat }}$

(1)

where the subscript $i$ denotes firms; $j$ denotes lines of insurance; $k$ denotes states; and $t$ denotes years. The $\alpha$ 's, $\beta$ 's, and $\delta$ 's are the coefficients to be estimated, and $\epsilon_{\mathrm{ijkt}}$ is the error term. We estimate equation (1) separately for each line of insurance to isolate line-specific relationships. We treat each state as a separate market since firms are regulated at the state level. The logarithmic specification treats proportional effects (such as halving or doubling) equally; this reduces any large outliers. ${ }^{21}$

The main variables of interest are size, as measured by national premiums in all lines, and the previous year's relative profitability. The national size variable reflects 
firms that are large because they either write in many states or many lines. Since we control for the lagged dependent variable, national size is distinct from the firm's recent experience in the line in the state. A firm's lagged relative profitability is its loss ratio in this previous year divided by the overall industry loss ratio for this line in the state in the previous year. This variable captures the profitability for a line in a state relative to the typically underwriting experience in the state. If there is some persistence in the relative profitability of firms operating in a state, this variable captures which firms have relatively good or bad opportunities in the state. if the firm was relatively unprofitably in this line last year, we would expect it to try to improve the line's profitability.

To measure the effects of organizational form, we include a stock company dummy variable (equal to one for stock companies) and an analogous variable for mutual-owned stock companies. We interact these dummy variables with the key variables of interest. The coefficients on the dummy variables capture any general differences in premiums across organizational forms. The coefficients on the terms interacting with relative profitability and national premiums earned capture whether stock companies respond differently than mutuals in relation to their underwriting environment. The interaction with national premiums allows large stock companies to differ from large mutual companies. Since our organizational form variables are simple dummy variables, they are a rather crude measure of differences across types of firms and do not capture heterogeneity within types of firms. For example, stock firms include both publicly-traded and privately-held companies. 
The state income variable is the state firm's aggregate income; ${ }^{22}$ it measures differences across states in the size of their markets. Unlike the state-specific fixedeffect variables, which control for state-specific effects, this variable changes over time. The year dummy variables capture any national trends in the profitability of writing a line of insurance. We set the year dummy variable for 1985 to zero to avoid singularity.

Table 4 reports the results from estimating equation (1). As expected, the coefficients on the lagged value of premiums are close to but less than 1 : they range from 0.73 to 0.94 . While the coefficients on relative profitability are often statistically significant, there is no pattern to their signs. Firms that have larger national premiums (either more states or more lines) tend to write more insurance in the state in each line. In all eight lines, the coefficients on the two types of stock companies are similar which suggests that in terms of scale of operations within a state, mutual-owned stock companies are more similar to stock companies than to mutuals.

To test whether organizational form affects total premiums, we examine the coefficients for the stock dummy, the mutual-owned stock dummy, and the interaction terms. The coefficients on each of the two stock dummy variables are negative and statistically significant at the 95 percent confidence level in all of the lines. This result suggests that even though stocks have larger firm-level national premiums, conditional on offering a line of insurance in a given state, they are smaller than mutuals. This difference is consistent with the observation that mutuals are more concentrated geographically and by line. 
One would expect stock companies to be more responsive to changes in profitability since they will respond more to the interest of wealth-maximizing shareholders than policyholders who may value stable insurance arrangements. Low relative levels of profitability (that is, high relative loss ratios) should lead stock companies to contract their operations. The interaction between the stock dummy and lagged relative profitability is negative and statistically significant in all eight lines of insurance; this is also true of all but one mutual-owned stock company. Thus, relative to mutual companies. stock companies write less insurance in states where they are less profitable. This result is consistent with our theory that stock companies are more likely to react to their underwriting environment in determining the amount of insurance that they write. The interaction terms for mutual-owned stocks are typically about one-half as large in absolute value as the interaction terms for stock companies. This pattern suggests that the reactions of mutual-owned stock companies are somewhere between the reactions of the other types of companies.

The coefficients for the stock dummy and mutual-owned stock dummy interacted with national premiums earned and are positive and statistically significant in all but three cases. The positive interaction term between stock and national premiums suggests that large national scale has a greater influence on the premiums written by stock companies.

\section{Loss Level Effects}

One problem with using total premiums as a measure of behavior is that the figure can increase either because the firm writes more policies, or because it charges 
a higher price for the same number of policies. As a second measure of firm behavior, we use the level of firm losses, and control for premiums earned during the same year. By including premiums earned in the equation, the results take as given any changes in premiums due to price or quantity changes. Thus, this equation measures firm behaviors aimed at reducing the level of claims, such as more stringent screening of applicants. For losses incurred, we estimate the following fixed effects equation:

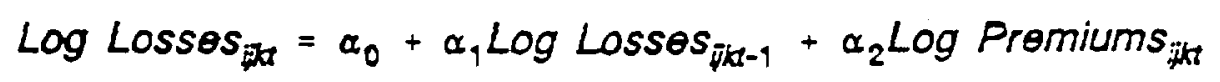

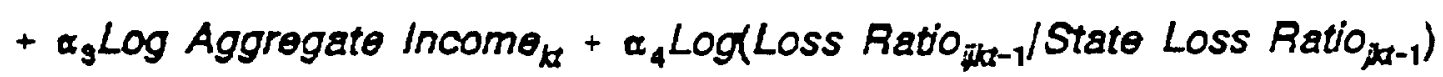

$+a_{5} \log$ National Premiums Eamod

$+\alpha_{8}$ Stock $_{1}+\alpha_{7}$ Mutual-Ownod Stock,

(2)

$$
\begin{aligned}
& +\alpha_{8} \text { Stock }_{\bar{p}} \times \text { Log }\left(\text { Loss Ratio } \text { Rtr-1 }_{\text {State Loss Ratio }} \text { Lta-1 }\right)
\end{aligned}
$$

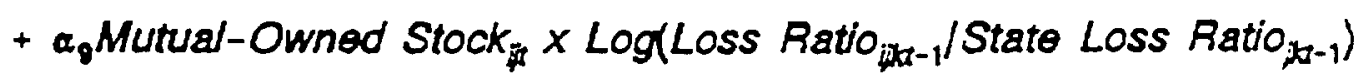

$$
\begin{aligned}
& \text { + } \alpha_{10} \text { Stock }_{\text {p }} \times \text { Log National Premiums Eamed } \\
& +\alpha_{11} \text { Mutual-OwnedStock }{ }_{p} \times \text { Log National Premiums Eamed } \\
& +\sum_{k} \beta_{k} \text { State }_{k}+\sum_{l} \delta_{t} \text { Year }_{t}+\epsilon_{j \mathrm{j} r}
\end{aligned}
$$

Table 5 presents the coefficients from estimating equation (2). As expected, the coefficients on both lagged losses and current premiums are positive and statistically significant. Many of the coefficients on relative profitability and on the interaction 
between the stock dummy and relative profitability are statistically significant.

However, there is no consistent pattern in the signs of the coefficients.

In eight of the nine instances in which the coefficient on the stock dummy or the mutual-owned stock dummy is statistically significant, it is positive. This pattern suggests that for a given amount of premiums, stock companies have more losses, a finding consistent with the historical claim that mutual companies are more careful in screening their applicants, or just secure a better mix. However, since the result is for a given amount of premiums less policyholder dividenas. it is not clear that mutuals pass this savings on to policyholders either in dividends or lower premiums. ${ }^{.3}$ Loss Ratio Effects

Our final measure of firm behavior is the loss ratio, a widely used measure of profitability for insurance. The loss ratio combines the effects of behaviors that change either premiums or losses. We estimate the following reduced-form fixed-effects equation: 
Log Loss Ratio $\alpha_{0}=\alpha_{0}+\alpha_{1} \log$ Aggregate Income $\theta_{k t}$

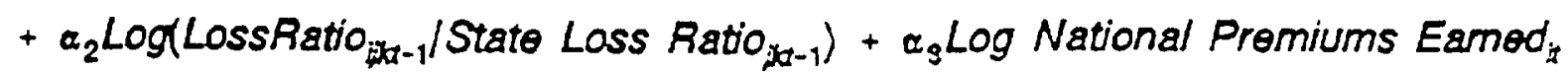

$+\alpha_{4}$ STock $_{1}+a_{5}$ Mutual-Owned Stock

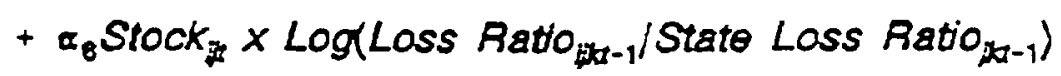

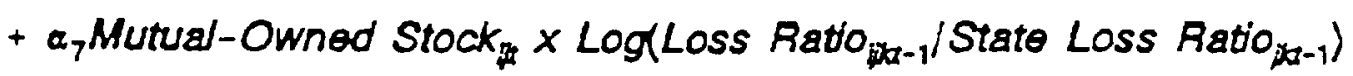

- $\alpha_{8}$ Stock $_{\text {p }} \times \log$ National Premiums Eamed

$+\alpha_{9}$ Mutual-Owned Stock $_{i r} \times$ Log National Premiums Eamed

$+\sum_{k} \beta_{x} \operatorname{Stat\theta }_{x} \times \sum_{t} \delta_{i} Y_{\theta \theta a r_{i}}-\epsilon_{i j}$

(3)

The structure of the equation is similar to the premium and loss equations. The size variable reflects differences in national firm size that may affect profitability. Larger firms may be able to weather worse underwriting environments if they are more efficient in other operations, such as investing.

Table 6 summarizes the regression results for equation (3). The lagged value of relative profitability has a positive effect on this year's profitability, suggesting that there is persistence in underwriting profitability. The mix of policies insured by a firm in the state and their relative performance tends to remain similar over time. Larger firms tend to have significantly higher loss ratios in every instance. Since these loss ratios do not adjust for underwriting expenses, the higher loss ratios of large firms may reflect that they benefit from economies of scale which give them lower administrative costs per dollar of losses. Alternatively, this may indicate that larger firms earn a higher return from investing their assets, allowing them to sustain somewhat lower 
underwriting profitability.

We do not find a discernable pattern whereby one organizational form outperforms the other, though the three types of firms are statistically different. This conclusion is consistent with earlier results from table 3 . The coefficient on the stock dummy is positive and statistically significant at the 95 percent confidence level for commercial multiple peril, general liability, and medical malpractice, but negative and statistically significant for homeowners multiple peril and commercial automobile property damage insurance. For mutual-owned stocks, the dummy variable effect is positive and statistically significant in only one case, but negative and statistically significant in five instances.

The coefficients for the interaction terms with relative profitability for both the stock dummy and mutual-owned stocks are mixed, with no consistent statistically significant pattern. The profitability of stock companies is statistically less persistent than that of mutual companies in four lines: commercial multiple peril, general liability, and commercial and private automobile property damage. Similarly, less persistence is observed for stock-owned mutuals in four lines: general liability, automobile private bodily injury, and both automobile physical damage lines. However, compared to mutual firms, the profitability of both stock companies and mutual-owned stock companies is statistically more persistent in two lines: medical malpractice and automobile commercial bodily injury. The profitability of stock companies and mutualowned stock companies tends to display mixed effects with respect to the role of size variations. Again, however the similarities between the coefficients for the two types of 
stock companies suggests that stock ownership is more important than who owns the stock.

v. Conclusion

Our results identify several differences between stocks (and mutual-owned stocks) and mutuals. ${ }^{24}$ First, while stock companies tend to collect more premiums than mutual companies at the national level, mutuals write more business than stocks on a per line, per state basis. This result is consistent with the belief that stock companies serve broader geographical areas and write more lines of insurance than mutuals. Second, relative to mutuals, stock companies have lower total premiums in lines and states in which they were relatively unprofitable in the previous year. This suggests that stock companies are more likely than mutuals to cut back their business in unprofitable situations. Third, for a given amount of premiums, stock companies have higher losses than mutuals. This is consistent with traditional arguments that mutuals are more careful in screening or better in attracting risks than stock companies.

In a number of cases, we found a notable lack of differences between stock and mutual companies. For example, neither form of organization has a consistently higher underwriting profitability than the other. Our most persistent and powerful result is that stock and mutual-owned stock companies are much quicker to exit unprofitable markets and expand operations in profitable markets. 


\section{Notes}

1. Savings and loans (S\&LS) are another notable example of the coexistence of stock and mutual firms. Hermalin and Wallace (1994) analyze differences in the level of efficiency of stock and mutual S\&Ls. As discussed by Berger. Cummins and Weiss (1995), comparing the efficiency of different types of insurance companies is complicated by the possibility of different organizational forms offering differentiated products. We abstract from issues of the level of efficiency of the organizational forms by concentrating on how firms respond to changes in their cperating environments.

2. The remainder of the industry consists of reciprocals $(5 \%)$, risk retention groups (2\%), U.S. branches of alien insurers (less than $1 \%$ ) and Lloyd's syndicates (less than 1\%). Reciprocals are similar to mutuals but, are not corporations and have an attorney-in-fact instead of a board of directors. We focus on stock and mutual companies since they dominate the market.

3. See Fama and Jensen (1983a and 1983b) for a general treatment of how agency costs affect business organizational form. Mayers and Smith (1981 and 1988) and Hansmann (1985) discuss these problems in the specific context of stock and mutual insurance companies.

4. Of course, this possibility also motivates government policies such as guarantee funds and investment limits. See Born (1994) and the references therein.

5. The unlimited liability of Uoyds' partners (names) was designed to provide the same reassurance, given that names had to be people of significant means.

6. Savings banks are a closely-related example of a market in which mutuals and for- 
profit organizations compete. In recent years, there has been a major movement to "demutualize" savings banks. There have been widespread allegations of insider enrichment. In most such demutualizations, a substantial capital value emerges almost overnight, suggesting that the mutual form may not have been optimal.

The hospital industry also has for-profit and nonprofit organizations competing in the same market. The nonprofits are given tax advantages, and also benefit from superior trust of potential customers. The for-profits can raise equity capital. Normally, for-profits are considered more efficient, but the evidence in the nospital sector does not support this expectation. Patel, Needleman and Zeckhauser (1994). 7. Some of the geographic concentration of mutuals may result from their initial development, frequently as an offshoot of fraternal organizations or other organizations where there were close relationships among the insureds.

8. The managers of mutuals may face pressure from different groups of policyholders, either by region or line of business. For example, policyholders in a profitable state would benefit if the mutual pulls out of an unprofitable state (see Hetherington, 1991 . p. 32).

9. Last year's profitability does not actually characterize a "change" in the firm's underwriting environment. Instead, the variation across firms in last year's profitability is used to describe differences in behavior in a particular line. An alternative measure from which to gauge current year behavior would be the trend of firm profitability in the particular line and state over the past two or more years.

10. See Bainbridge (1952), Heflebower (1980, chapter 12) and Hansmann (1985) for 
more historical information on the industry.

11. We exclude workers' compensation from our analysis because for the period studied, this line was subject to numerous changes in state regulations, including many changes in benefit provisions and the emergence of large residual market pools. 12. Wilcoxon rank-sum tests were performed to test whether the distributions of firm size for stocks and mutuals are the same. For premiums earned in all lines, stock companies are larger than mutuals. However, by line of insurance, this size difference is not clear. Of the eight lines analyzed. stock companies were found to be larger than mutuals in only one line, general liability. Mutuals are larger than stock companies in five lines: homeowners' multiple peril, medical malpractice, automobile personal bodily injury, automobile personal property damage, and automobile commercial property damage. No significant difference was found for the remaining two lines.

13. In 1986, the Federal government amended the 1981 Risk Retention Act, which facilitated the formation of risk retention pools, or insurance buyers' groups by manufacturers. The 1986 amendment extended this option to all buyers of commercial liability coverage, and it appears to have been instrumental in drawing some business away from the more traditional organizational forms.

14. The loss ratios are not adjusted for administrative expenses. If stocks and mutuals differ in their administrative expenses, these comparisons may not accurately reflect differences in profitability. Several recent articles that evaluate the efficiency of insurers discuss the importance of administrative expenses. See Pauly, Kunreuther, and 
Kleindorfer (1986), and Cummins and Weiss (1993).

15. For a discussion of the liability crisis and the reforms, see Viscusi (1991) and Born and Viscusi (1994).

16. See Hetherington (1991), pp. 31-32, for a discussion of the differences in incentives of policyholders and shareholders.

17. See Cummins and Harrington (1987). More refined regulatory regime breakdowns did not generate significant effects.

18. There are several reasons why these differences in broad regulatory regimes did not differentially affect stock and mutual firms. First, we only measured legislated differences in regulation and not differences in the stringency of enforcement.

Second, regulation and firm location choices could be endogenous.

19. For a review of the economic aspects of insurance market operation, see Dionne (1992).

20. The reported results are from unweighted ordinary least squares regressions. Alternatively, we could weight by firm asset size; however, since our unit of observation is firm activity within a state, national firm-level total assets may not be the appropriate weighting variable.

21. The logarithmic specifications also had much more explanatory power than the linear specifications.

22. Income data are from the U.S. Department of Commerce, Survey of Current Business.

23. While this difference suggests that mutuals have higher underwriting profits than 
stock companies, the two organizational forms could differ in their costs (e.g., mutuals spend more on screening) or in service levels.

24. Several caveats should be mentioned. First, the regressions above take the location of stock and mutual companies as exogenous. If differences in the underwriting environment across states and lines of insurance differentially affect firms' entry and exit decisions into markets, then location is endogenous, and the results may be biased. Second, we have focused on agency cost differences in organizational forms. These firms also differ in their access to equity markets. To better address how this difference affects firm behavior, however, one would need to distinguish between publicly-traded and privately-held stock companies as well as account for the consolidated group structure of insurance firms. 


\section{References}

Bainbridge, John. 1952. Biography of an Idea: The Story of Mutual Fire and

Casualiy Insurance, Garden City, NY: Doubleday \& Company.

Berger, Allen, J. David Cummins and Mary A. Weiss. 1995. "The Coexistence of Alternative Distribution Systems for the Same Financial Service: The Case of Property-Liability Insurance," working paper, Wharton School, University of Pennsylvania.

Born, Patricia. 1994. Essays on Insurance Regulation and Insolvency: Empirical Evidence from the Property-Casualty Insurance Industry Ph.D. dissertation, Duke University.

Born, Patricia and W. Kip Viscusi. 1994. "Insurance Market Responses to the 1980 s Liability Reforms: An Analysis of Firm-Level Data," Journal of Risk and Insurance vol. 61 , no. 2.

Cummins, J. David and Mary A. Weiss. 1993. "Measuring Cost Efficiency in the Property-Liability Insurance Industry," Journal of Banking and Finance, vol. 17, pp. $463-482$.

Cummins, J. David and Scott E. Harrington. 1987. "The Impact of Rate Regulation in U.S. Property-Liability Insurance Markets: A Cross-Sectional Analysis of Individual Firm Loss Ratios," The Geneva Papers on Risk and Insurance, vol. 12, pp. 50-62.

Dionne, Georges, editor. 1992. Contributions to Insurance Economics Boston: Kuwer Academic Publishers. 
Fama, Eugene F. and Michael C. Jensen. 1983a. "Separation of Ownership and Control," Jeurnal of Law and Economics vol. 26, pp. 301-325.

................... 1983b. "Agency Problems and Residual Claims," Journal of Law and Economics, vol. 26, pp. 327-349. Hansmann, Henry. 1985. "The Organization of Insurance Companies: Mutual versus Stock," Journal of Law, Economics, and Organization vol. 1, pp. 125-153. Heflebower, Richard B. 1980. Cooperatives and Mutuals in the Market System, Madison, WI: University of Wisconsin Press.

Hermalin, Benjamin E. and Nancy E. Wallace. 1994. "The Determinants of Efficiency and Solvency in Savings and Loans," The RAND Journal of Economics, vol. 25, no. 3 , pp. 361-381.

Hetherington, John A. C. 1991. Mutual and Cooperative Enterprises: An Analysis of Customer-owned Firms in the United States, Charlottesville, VA: University of Virginia Press.

Lamm-Tennant, Joan and Laura T. Starks. 1993. "Stock versus Mutual Ownership Structures: The Risk Implications," Journal of Business, vol. 66, pp. 29-46. Mayers, David and Clifford W. Smith, Jr. 1994. "Managerial Discretion, Regulation, and Stock Insurer Ownership Structure," Journal of Risk and Insurance vol. 61, no. 4 , pp. $638-655$.

1988. "Ownership Structure across Lines of Property-Casualty Insurance," Journal of Law and Economics, vol. 31, pp. 351-378.

1981. "Contractual Provisions, Organizational Structure, and Conflict 
Control in Insurance Markets," Journal of Business vol. 54, pp. 407-434.

Patel, Jayendu, Jack Needleman, and Richard Zeckhauser. 1994. "Changing Fortunes, Hospital Behaviors, and Ownership Forms," faculty research working paper, John F. Kennedy School of Government, Harvard University, no. R94-17. Pauly, Mark V., Howard Kunreuther, and Paul Kleindorfer. 1986. "Regulation and Quality Competition in the U.S. Insurance Industry," in Jorg Finsinger and Mark Pauly, eds., The Economics of Insurance Regulation New York: St Martin's Press.

Pound, John and Richard Zeckhauser. 1990. "Are Large Shareholders Effective Monitors? An Investigation of Share Ownership and Corporate Performance," Glenn Hubbard, editor, Asymmetric Information, Corporate Finance, and Investment, Chicago: University Chicago Press, pp. 149-182.

Viscusi, W. Kip. 1991. Reforming Products Liability Cambridge, MA: Harvard University Press. 
Born, Gentry, Viscusi, Zeckhauser

Table 1: Size Comparison of Stock and Mutuaj Companies, 1991

\begin{tabular}{lcc}
\hline \hline & Stock & Mutual \\
\hline Homeowners' Multiple Peril & & \\
\hline Number of Firms & 180 & 200 \\
\hline Percent of industry & $37.5 \%$ & $58.6 \%$ \\
\hline Premiums (millions) & $\$ 404.13$ & $\$ 632.27$ \\
\hline Mean premium per company $(\$ 000)$ & $\$ 2,245.16$ & $\$ 3,161.37$ \\
\hline Median premium per company $(\$ 000)$ & $\$ 255.42$ & $\$ 661.00$ \\
\hline Commercial Multiple Peril & & 352 \\
\hline Number of Firms & 695 & $19.1 \%$ \\
\hline Percent of industry & $70.5 \%$ & $\$ 3,693.33$ \\
\hline Premiums (millions) & $\$ 2,844.13$ \\
\hline Mean premiums per company $(\$ 000)$ & $\$ 19,656.32$ & $\$ 10,492.41$ \\
\hline Median premiums per company $(\$ 000)$ & $\$ 139.59$ & \\
\hline Number of Firms & & \\
\hline & & \\
\hline
\end{tabular}


Table 1 continued

\begin{tabular}{|c|c|c|}
\hline Percent of industry & $52.4 \%$ & $5.5 \%$ \\
\hline Premiums (millions) & $\$ 18,908.59$ & $\$ 1,977.14$ \\
\hline Mean premiums per company $(\$ 000)$ & $\$ 19,080.32$ & $\$ 5,616.86$ \\
\hline Median premiums per company $(\$ 000)$ & $\$ 1,659.16$ & $\$ 307.74$ \\
\hline \multicolumn{3}{|l|}{ Medical Malpractice } \\
\hline Number of Firms & 199 & 33 \\
\hline Percent of industry & $39.9 \%$ & $16.9 \%$ \\
\hline Premiums (millions) & $\$ 2,620.74$ & $\$ 1,110.26$ \\
\hline Mean premiums per company $(\$ 000)$ & $\$ 13,169.57$ & $\$ 33,644.24$ \\
\hline Median premiums per company $(\$ 000)$ & $\$ 1,492.05$ & $\$ 12,800.43$ \\
\hline \multicolumn{3}{|l|}{ Automobile Private Bodily injury } \\
\hline Number of Firms & 813 & 206 \\
\hline Percent of industry & $56.2 \%$ & $34.6 \%$ \\
\hline Premiums (millions) & $\$ 28,823.71$ & $\$ 17,754.63$ \\
\hline Mean premiums per company $(\$ 000)$ & $\$ 35,453.52$ & $\$ 86,187.54$ \\
\hline Median premiums per company $(\$ 000)$ & $\$ 6,292.32$ & $\$ 11,268.67$ \\
\hline
\end{tabular}




\section{Automobile Commercial Bodily Injury}

\begin{tabular}{lcc}
\hline Number of Firms & 783 & 176 \\
\hline Percent of industry & $78.7 \%$ & $18.0 \%$ \\
\hline Premiums (millions) & $\$ 10,160.48$ & $\$ 2,324.44$ \\
\hline Mean premiums per company $(\$ 000)$ & $\$ 12,976.34$ & $\$ 13,207.07$ \\
\hline Median premiums per company $(\$ 000)$ & $\$ 1,699.93$ & $\$ 2,566.24$ \\
\hline
\end{tabular}

Automobile Private Physical Damage

\begin{tabular}{lcc}
\hline Number of Firms & 852 & 209 \\
\hline Percent of industry & $53.3 \%$ & $37.7 \%$ \\
\hline Premiums (millions) & $\$ 16,654.40$ & $\$ 11,756.43$ \\
\hline Mean premiums per company (\$000) & $\$ 19,547.42$ & $\$ 56.250 .84$ \\
\hline Median premiums per company (\$000) & $\$ 3,570.74$ & $\$ 7,737.12$ \\
\hline Automobile Commercial Physical Damage & & 168 \\
\hline Number of Firms & 754 & $19.9 \%$ \\
\hline Percent of industry & $77.1 \%$ & $\$ 894.93$ \\
\hline Premiums (millions) & $\$ 3,471.47$ & \\
\hline
\end{tabular}


Table 1 continued

\begin{tabular}{lcc}
\hline Mean premiums per company $(\$ 000)$ & $\$ 4,604.07$ & $\$ 5,326.96$ \\
\hline Median premiums per company $(\$ 000)$ & $\$ 798.18$ & $\$ 1,241.26$ \\
\hline
\end{tabular}


Table 2: Percent of Industry Business, : 984 and 1991

\begin{tabular}{|c|c|c|c|c|}
\hline & \multicolumn{2}{|c|}{1984} & \multicolumn{2}{|c|}{1991} \\
\hline & Stocks & Mutuals & Stocks & Mutuals \\
\hline Homeowners & 43 & 54 & 36 & 58 \\
\hline \multicolumn{5}{|l|}{ Multiple Peril } \\
\hline Commercial & 75 & 19 & 70 & 19 \\
\hline \multicolumn{5}{|l|}{ Multiple Peril } \\
\hline General Liability & 87 & 11 & 52 & 5 \\
\hline Medical & 58 & 17 & 40 & 17 \\
\hline \multicolumn{5}{|l|}{ Malpractice } \\
\hline Auto. Private & 58 & 33 & 56 & 35 \\
\hline \multicolumn{5}{|l|}{ Bodily Injury } \\
\hline Auto. Commercial & 79 & 18 & 79 & 18 \\
\hline \multicolumn{5}{|l|}{ Bodily Injury } \\
\hline Auto. Private & 56 & 35 & 53 & 38 \\
\hline Property Damage & & & & \\
\hline
\end{tabular}


Table 2 continued

$\begin{array}{lllll}\text { Auto Commercial } & 78 & 19 & 77 & 20 \\ \text { Property Damage } & & & & \end{array}$

The remaining business in the industry is written by Lloya's. reciprocals, risk retention groups and reinsurers. 


\section{Table 3}

Loss Ratios of Stock and Mutual Companies:

By Line of Business and Year

\begin{tabular}{|c|c|c|c|c|c|c|c|c|}
\hline & 1984 & 1985 & 1986 & 1987 & 1988 & 1989 & 1990 & 1991 \\
\hline \multicolumn{9}{|c|}{ Homeowners Multiple Peril } \\
\hline \multirow[t]{2}{*}{ Stock } & 0.76 & 0.73 & 0.62 & 0.51 & 0.61 & 0.70 & 0.65 & 0.68 \\
\hline & $(0.96)$ & 0.57 & $(0.83)$ & $(1.50)$ & $(1.31)$ & $(4.95)$ & $(1.15)$ & $(1.01)$ \\
\hline \multirow[t]{2}{*}{ Mutual } & 0.79 & 0.72 & 0.68 & 0.58 & 0.64 & 0.70 & 0.71 & 0.75 \\
\hline & $(0.23)$ & $(0.33)$ & $(0.30)$ & $(0.21)$ & (3.15) & $(0.33)$ & $(0.24)$ & $(0.25)$ \\
\hline \multicolumn{9}{|c|}{ Commercial Multiple Peril } \\
\hline \multirow[t]{2}{*}{ Stock } & 0.67 & 0.67 & 0.59 & 0.53 & 0.57 & 0.71 & 0.72 & 0.77 \\
\hline & $(0.76)$ & $(0.91)$ & $(1.71)$ & $(1.06)$ & $(2.53)$ & $(2.14)$ & $(1.42)$ & $(1.23)$ \\
\hline \multirow[t]{2}{*}{ Mutual } & 0.64 & 0.65 & 0.58 & 0.53 & 0.56 & 0.67 & 0.65 & 0.69 \\
\hline & $(0.26)$ & $(0.28)$ & $(0.23)$ & $(0.18)$ & $(0.24)$ & $(0.55)$ & $(0.26)$ & $(0.27)$ \\
\hline \multicolumn{9}{|c|}{ General Liability } \\
\hline \multirow[t]{2}{*}{ Stock } & 0.99 & 1.14 & 0.75 & 0.69 & 0.62 & 0.70 & 0.64 & 0.65 \\
\hline & (3.82) & (9.85) & $(4.65)$ & (16.14) & (10.99) & (12.37) & (25.29) & (4.32) \\
\hline \multirow[t]{2}{*}{ Mutual } & 0.81 & 0.83 & 0.67 & 0.70 & 0.59 & 0.58 & 0.64 & 0.56 \\
\hline & $(1.40)$ & $(1.64)$ & $(0.89)$ & (3.91) & $(1.18)$ & $(1.48)$ & $(1.21)$ & (1.46) \\
\hline
\end{tabular}


Table 3 continued

Medical Malpractice

\begin{tabular}{ccccccccc}
\hline Stock & 0.99 & 1.14 & 0.87 & 0.77 & 0.65 & 0.58 & 0.60 & 0.55 \\
& $(3.95)$ & $(11.00)$ & $(18.63)$ & $(15.96)$ & $(11.34)$ & $(13.98)$ & $(16.93)$ & $(8.15)$ \\
\hline Mutual & 1.21 & 1.21 & 1.10 & 1.10 & 0.90 & 0.48 & 0.54 & 0.55 \\
& $(13.59)$ & $(3.10)$ & $(2.63)$ & $(0.61)$ & $(1.85)$ & $(0.56)$ & $(0.44)$ & $(0.58)$ \\
\hline Automobile Private Bodily Injury & & & & & & \\
\hline Stock & 0.69 & 0.70 & 0.69 & 0.67 & 0.67 & 0.70 & 0.71 & 0.78 \\
& $(1.80)$ & $(2.29)$ & $(2.49)$ & $(6.12)$ & $(1.35)$ & $(2.25)$ & $(0.96)$ & $(2.89)$ \\
\hline Mutual & 0.70 & 0.71 & 0.68 & 0.68 & 0.71 & 0.73 & 0.72 & 0.77 \\
& $(0.23)$ & $(2.32)$ & $(1.61)$ & $(1.53)$ & $(1.24)$ & $(0.29)$ & $(2.79)$ & $(1.36)$
\end{tabular}

Automobile Commercial Bodily Injury

\begin{tabular}{|c|c|c|c|c|c|c|c|c|}
\hline Stock & $\begin{array}{c}0.81 \\
(2.59)\end{array}$ & $\begin{array}{c}0.69 \\
(3.26)\end{array}$ & $\begin{array}{c}0.51 \\
(3.72)\end{array}$ & $\begin{array}{c}0.50 \\
(7.06)\end{array}$ & $\begin{array}{r}0.53 \\
(3.79)\end{array}$ & $\begin{array}{c}0.56 \\
(2.58)\end{array}$ & $\begin{array}{c}0.62 \\
(2.90)\end{array}$ & $\begin{array}{r}0.69 \\
(6.52)\end{array}$ \\
\hline Mutual & $\begin{array}{r}0.79 \\
(0.62)\end{array}$ & $\begin{array}{c}0.67 \\
(5.41)\end{array}$ & $\begin{array}{c}0.55 \\
(0.53)\end{array}$ & $\begin{array}{c}0.55 \\
(0.34)\end{array}$ & $\begin{array}{c}0.65 \\
(0.61)\end{array}$ & $\begin{array}{c}0.66 \\
(1.33)\end{array}$ & $\begin{array}{c}0.64 \\
(0.64)\end{array}$ & $\begin{array}{r}0.66 \\
(0.76)\end{array}$ \\
\hline \multicolumn{9}{|c|}{ Automobile Private Physical Damage } \\
\hline Stock & $\begin{array}{c}0.66 \\
(0.30)\end{array}$ & $\begin{array}{c}0.64 \\
(0.32)\end{array}$ & $\begin{array}{c}0.60 \\
(0.68)\end{array}$ & $\begin{array}{c}0.56 \\
(0.29)\end{array}$ & $\begin{array}{c}0.58 \\
(0.24)\end{array}$ & $\begin{array}{c}0.61 \\
(0.74)\end{array}$ & $\begin{array}{c}0.61 \\
(0.69)\end{array}$ & $\begin{array}{r}0.55 \\
(2.77)\end{array}$ \\
\hline
\end{tabular}


Table 3 continued

\begin{tabular}{ccccccccc}
\hline Mutual & 0.69 & 0.68 & 0.64 & 0.60 & 0.63 & 0.67 & 0.66 & 0.59 \\
& $(0.12)$ & $(0.12)$ & $(0.13)$ & $(0.12)$ & $(0.19)$ & $(0.12)$ & $(0.11)$ & $(0.13)$ \\
\hline Automobile Commercial Physical Damage & & & & \\
\hline Stock & 0.69 & 0.58 & 0.45 & 0.41 & 0.45 & 0.50 & 0.49 & 0.45 \\
& $(0.46)$ & $(0.58)$ & $(0.62)$ & $(4.05)$ & $(8.71)$ & $(0.51)$ & $(0.83)$ & $(0.62)$ \\
\hline Mutual & 0.72 & 0.67 & 0.54 & 0.47 & 0.48 & 0.57 & 0.56 & 0.52 \\
& $(0.41)$ & $(0.29)$ & $(0.20)$ & $(0.19)$ & $(0.19)$ & $(0.39)$ & $(0.21)$ & $(0.43)$ \\
\hline \hline
\end{tabular}


I able 4: Log remmurns Hegression Hesums, |yos-ıy |

Insurance Firm-level Data

(standard errors in parentheses)

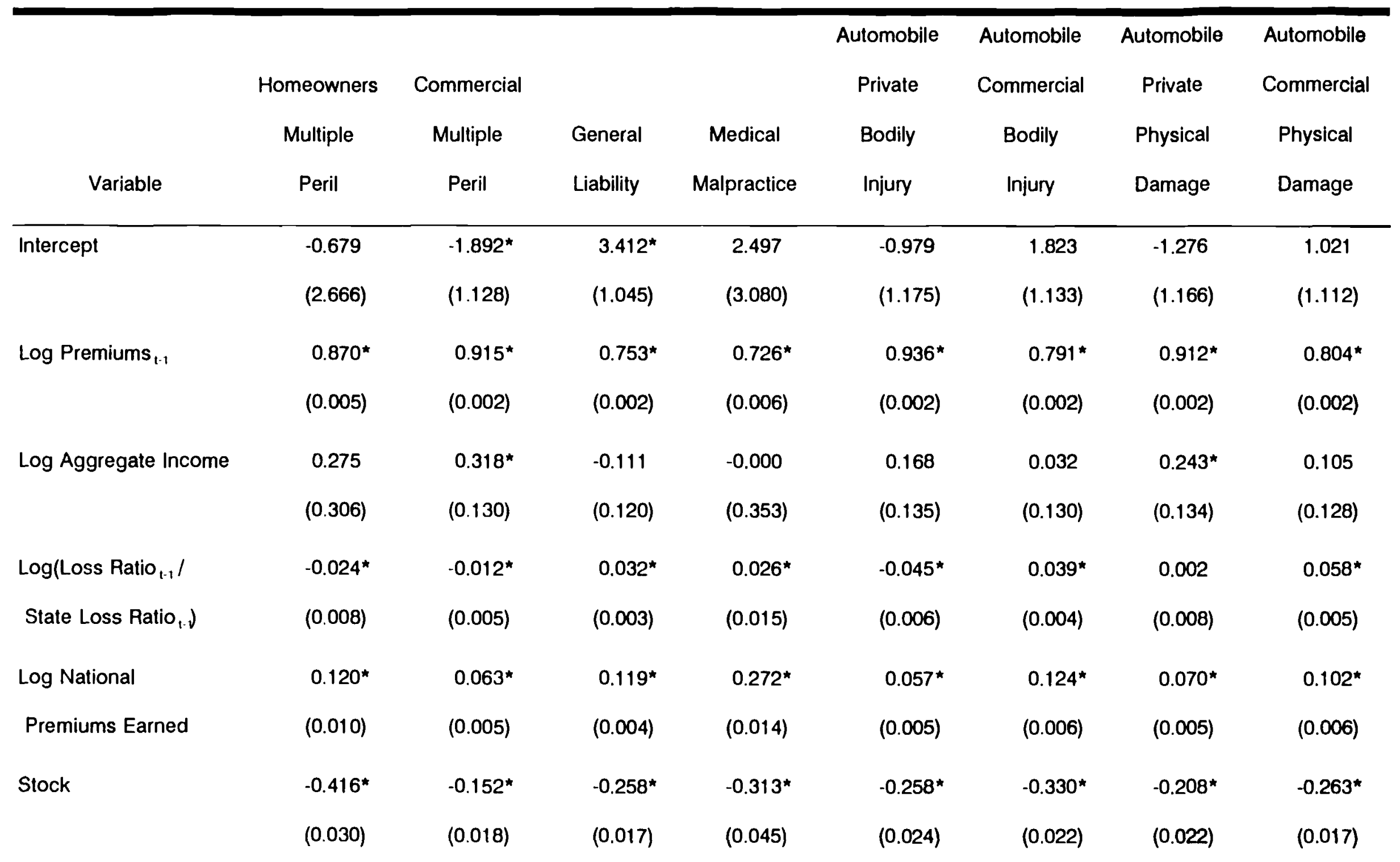




\begin{tabular}{|c|c|c|c|c|c|c|c|c|}
\hline \multirow[t]{2}{*}{ Mutual-Owned Stock } & $-0.383^{*}$ & $-0.175^{\star}$ & $-0.334^{\star}$ & $-0.360^{\star}$ & $-0.269^{\star}$ & $-0.402^{\star}$ & $-0.230^{\star}$ & $-0.338^{*}$ \\
\hline & $(0.030)$ & $(0.019)$ & $(0.018)$ & $(0.046)$ & $(0.026)$ & $(0.023)$ & $(0.025)$ & $(0.018)$ \\
\hline Stock * & $-0.029^{\star}$ & $-0.073^{\star}$ & $-0.042^{\star}$ & $-0.077^{\star}$ & $-0.051^{\star}$ & $-0.049^{*}$ & $-0.092^{\star}$ & $-0.079^{*}$ \\
\hline Log(Loss Ratio ${ }_{1,1} /$ & $(0.010)$ & $(0.006)$ & $(0.004)$ & $(0.017)$ & $(0.006)$ & $(0.005)$ & $(0.009)$ & $(0.005)$ \\
\hline \multicolumn{9}{|l|}{ State Loss Ratio,.$)$} \\
\hline Mutual-Owned & -0.006 & $-0.038^{\star}$ & $-0.046^{\star}$ & $-0.040^{\star}$ & $-0.027^{\star}$ & $-0.037^{\star}$ & $-0.041^{*}$ & $-0.055^{*}$ \\
\hline Stock * & $(0.010)$ & $(0.005)$ & $(0.004)$ & $(0.016)$ & $(0.007)$ & $(0.005)$ & $(0.009)$ & $(0.005)$ \\
\hline \multicolumn{9}{|l|}{ Log(Loss Ratio, 1} \\
\hline \multicolumn{9}{|l|}{ State Loss Ratio..J } \\
\hline Stock * Log National & 0.013 & $0.015^{\star}$ & $0.073^{\star}$ & 0.018 & $0.061^{\star}$ & $0.069^{\star}$ & $0.047^{\star}$ & $0.077^{\star}$ \\
\hline Premiums Earned & $(0.013)$ & $(0.006)$ & $(0.005)$ & $(0.015)$ & $(0.006)$ & $(0.007)$ & $(0.006)$ & $(0.007)$ \\
\hline Mutual-Owned Stock * & $0.048^{\star}$ & $0.018^{\star}$ & $0.101^{\star}$ & 0.012 & $0.047^{\star}$ & $0.085^{\star}$ & $0.040^{\star}$ & $0.088^{*}$ \\
\hline Log National & $(0.013)$ & $(0.006)$ & $(0.005)$ & $(0.014)$ & $(0.007)$ & $(0.007)$ & $(0.007)$ & $(0.007)$ \\
\hline \multicolumn{9}{|l|}{ Premiums Earned } \\
\hline $\mathrm{R}^{-2}$ & 0.847 & 0.879 & 0.844 & 0.861 & 0.873 & 0.811 & 0.851 & 0.809 \\
\hline
\end{tabular}

\section{Each equation also includes a set of six dummy variables for 1986-1991 and 49 state dummy variables.}

*Denotes coefficients that are statistically significant at the 95 percent confidence level, two-tailed test. 
Table 5: Log Losses Regression Results, 1985-1991

Insurance Firm-level Data

(standard errors in parentheses)

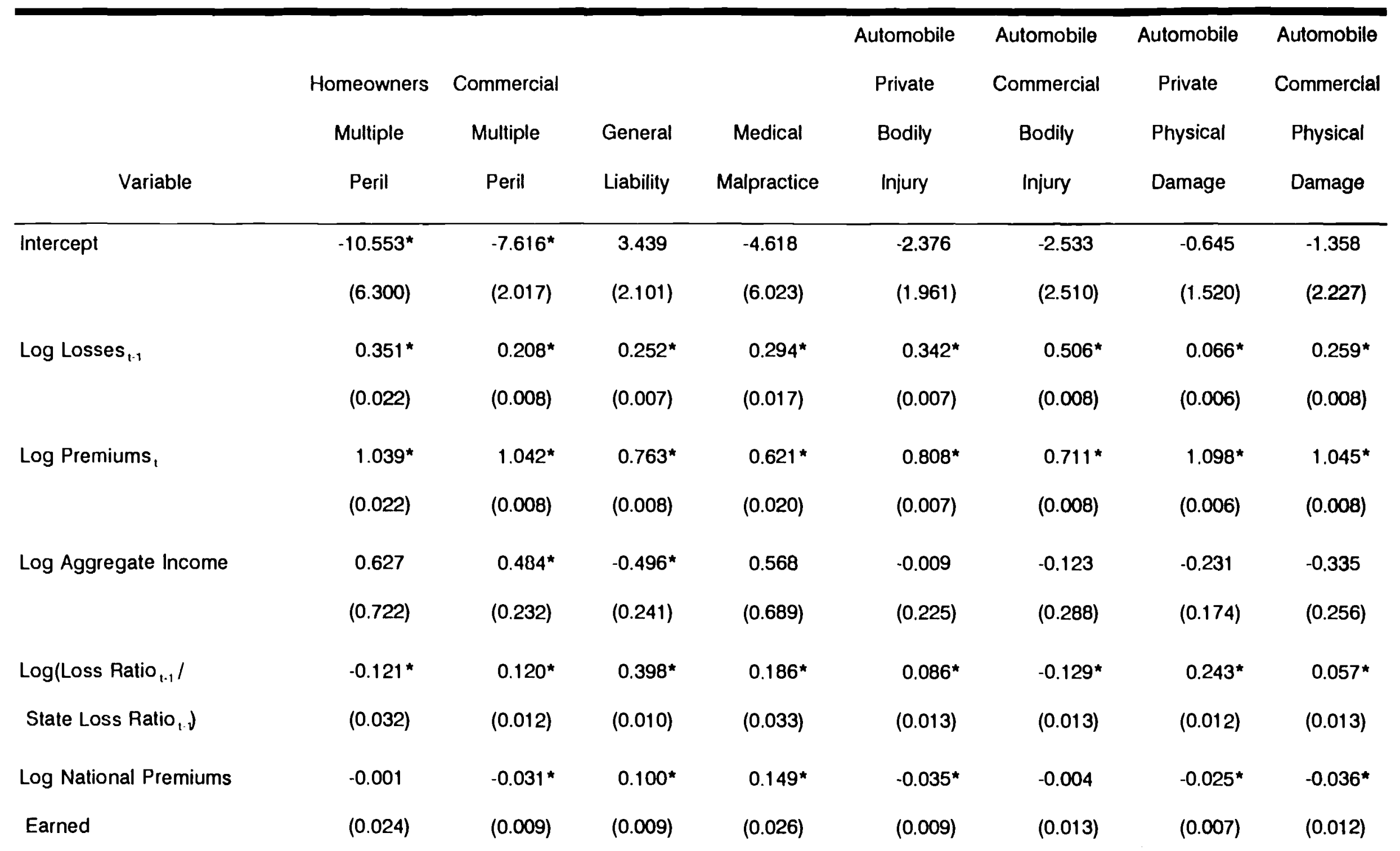




\begin{tabular}{|c|c|c|c|c|c|c|c|c|}
\hline \multirow[t]{2}{*}{ Stock } & -0.117 & $0.255^{\star}$ & $0.132^{\star}$ & $0.370^{\star}$ & 0.021 & $0.123^{\star}$ & $0.063^{\star}$ & -0.056 \\
\hline & $(0.072)$ & $(0.032)$ & $(0.034)$ & $(0.091)$ & $(0.040)$ & $(0.048)$ & $(0.029)$ & $(0.034)$ \\
\hline \multirow[t]{2}{*}{ Mutual-Owned Stock } & 0.041 & $0.176^{\star}$ & $0.267^{\star}$ & -0.107 & 0.018 & $0.219^{\star}$ & -0.012 & $-0.064^{\star}$ \\
\hline & $(0.071)$ & $(0.034)$ & $(0.038)$ & (0.093) & $(0.044)$ & $(0.052)$ & $(0.032)$ & $(0.037)$ \\
\hline Stock * Log(Loss Ratio ${ }_{t-1} /$ & $0.046^{\star}$ & -0.011 & $-0.110^{\star}$ & 0.043 & 0.003 & $0.139^{\star}$ & $-0.026^{\star}$ & $-0.027^{\star}$ \\
\hline State Loss Ratio, $\downarrow$ & $(0.023)$ & $(0.010)$ & $(0.008)$ & $(0.034)$ & $(0.011)$ & $(0.010)$ & $(0.012)$ & $(0.010)$ \\
\hline Mutual-Owned Stock * & $0.071^{\star}$ & $0.028^{\star}$ & $-0.146^{\star}$ & $0.071^{\star}$ & -0.014 & $0.141^{\star}$ & -0.003 & $-0.020^{*}$ \\
\hline Log(Loss Ratio, 1 & $(0.022)$ & $(0.010)$ & $(0.009)$ & $(0.032)$ & $(0.011)$ & $(0.011)$ & $(0.012)$ & $(0.011)$ \\
\hline \multicolumn{9}{|l|}{ State Loss Ratio, $)$} \\
\hline Stock * Log National & 0.028 & $-0.064^{\star}$ & $0.022^{\star}$ & $-0.087^{\star}$ & 0.014 & -0.006 & $-0.017^{\star}$ & $-0.025^{\star}$ \\
\hline Premiums Earned & $(0.031)$ & $(0.011)$ & $(0.010)$ & $(0.028)$ & $(0.010)$ & $(0.015)$ & $(0.008)$ & (0.013) \\
\hline Mutual-Owned Stock * & -0.045 & $-0.037^{\star}$ & $-0.031^{*}$ & $0.054^{\star}$ & $0.029^{\star}$ & $-0.046^{\star}$ & $0.020^{\star}$ & 0.004 \\
\hline Log National Premiums & $(0.030)$ & $(0.011)$ & $(0.010)$ & $(0.027)$ & $(0.011)$ & $(0.016)$ & $(0.009)$ & $(0.014)$ \\
\hline \multicolumn{9}{|l|}{ Earned } \\
\hline$r^{2}$ & 0.747 & 0.828 & 0.791 & 0.785 & 0.822 & 0.729 & 0.854 & 0.737 \\
\hline
\end{tabular}

Each equation also includes a set of six dummy variables for 1986-1991 and 49 state dummy variables.

*Denotes coefficients that are statistically significant at the 95 percent confidence level, two-tailed test. 
Table 6: Log Loss Ratio Regression Hesults, 1985-1991

Insurance Firm-level Data

(standard errors in parentheses)

\begin{tabular}{|c|c|c|c|c|c|c|c|c|}
\hline \multirow[b]{4}{*}{ Variable } & \multirow{3}{*}{$\begin{array}{c}\text { Homeowners } \\
\text { Multiple }\end{array}$} & \multirow[b]{2}{*}{ Commercial } & \multirow[b]{3}{*}{ General } & \multirow[b]{3}{*}{ Medical } & \multirow{2}{*}{$\begin{array}{c}\text { Automobile } \\
\text { Private }\end{array}$} & \multirow{2}{*}{$\begin{array}{l}\text { Automobile } \\
\text { Commercial }\end{array}$} & \multirow{2}{*}{$\begin{array}{c}\text { Automobile } \\
\text { Private }\end{array}$} & \multirow{2}{*}{$\begin{array}{l}\text { Automobile } \\
\text { Commercial }\end{array}$} \\
\hline & & & & & & & & \\
\hline & & Multiple & & & Bodily & Bodily & Physical & Physical \\
\hline & Peril & Peril & Liability & Malpractice & Injury & Injury & Damage & Damage \\
\hline \multirow[t]{2}{*}{ Intercept } & -6.489 & $-8.429^{\star}$ & 1.844 & -4.815 & -1.790 & $-4.496^{\star}$ & -0.889 & -2.299 \\
\hline & $(6.622)$ & (2.103) & (2.124) & (6.163) & (2.016) & (2.592) & $(1.564)$ & (2.303) \\
\hline \multirow[t]{2}{*}{ Log Aggregate Income } & 0.656 & $0.863^{\star}$ & -0.312 & 0.494 & 0.066 & 0.295 & -0.027 & 0.080 \\
\hline & $(0.759)$ & $(0.241)$ & $(0.244)$ & $(0.705)$ & $(0.231)$ & $(0.297)$ & $(0.179)$ & $(0.264)$ \\
\hline Log(Loss Ratio ${ }_{t-1} /$ & $0.414^{\star}$ & $0.477^{\star}$ & $0.655^{\star}$ & $0.458^{\star}$ & $0.522^{\star}$ & $0.467^{\star}$ & $0.418^{\star}$ & $0.447^{\star}$ \\
\hline State Loss Ratio, $\mathcal{J}$ & $(0.020)$ & $(0.009)$ & $(0.007)$ & $(0.030)$ & $(0.010)$ & $(0.010)$ & $(0.011)$ & $(0.009)$ \\
\hline Log National Premiums & $0.178^{\star}$ & $0.099^{\star}$ & $0.110^{\star}$ & $0.067^{\star}$ & $0.044^{\star}$ & $0.096^{\star}$ & $0.069^{\star}$ & $0.114^{\star}$ \\
\hline Earned & $(0.025)$ & $(0.009)$ & $(0.008)$ & $(0.025)$ & $(0.009)$ & $(0.013)$ & $(0.007)$ & $(0.012)$ \\
\hline \multirow[t]{2}{*}{ Stock } & $-0.598^{\star}$ & $0.126^{\star}$ & $0.082^{\star}$ & $0.437^{\star}$ & 0.015 & -0.012 & -0.009 & $-0.196^{\star}$ \\
\hline & $(0.074)$ & (0.033) & $(0.034)$ & $(0.093)$ & $(0.041)$ & $(0.049)$ & $(0.030)$ & $(0.035)$ \\
\hline \multirow[t]{2}{*}{ Mutual-Owned Stock } & $-0.521^{\star}$ & $-0.083^{*}$ & $0.192^{\star}$ & -0.023 & $-0.086^{\star}$ & -0.050 & $-0.126^{\star}$ & $-0.288^{\star}$ \\
\hline & $(0.072)$ & $(0.035)$ & $(0.037)$ & $(0.094)$ & $(0.045)$ & $(0.053)$ & (0.033) & $(0.038)$ \\
\hline
\end{tabular}


l aule b commutu

\begin{tabular}{|c|c|c|c|c|c|c|c|c|}
\hline Stock * Log(Loss Ratio ${ }_{t-1} /$ & -0.022 & $-0.037^{\star}$ & $-0.115^{\star}$ & $0.065^{\star}$ & -0.011 & $0.098^{\star}$ & $-0.061 *$ & $-0.072^{\star}$ \\
\hline State Loss Ratio ${ }_{t} \cdot \vec{J}$ & $(0.024)$ & $(0.011)$ & $(0.008)$ & $(0.034)$ & $(0.011)$ & $(0.011)$ & $(0.012)$ & $(0.010)$ \\
\hline Mutual-Owned Stock * & 0.016 & -0.009 & $-0.153^{\star}$ & $0.083^{\star}$ & $-0.031^{\star}$ & $0.092^{\star}$ & $-0.029^{\star}$ & $-0.065^{\star}$ \\
\hline Log(Loss Ratio $\left.{ }_{t-1}\right)$ & $(0.024)$ & $(0.010)$ & $(0.009)$ & $(0.032)$ & $(0.011)$ & $(0.011)$ & $(0.012)$ & $(0.011)$ \\
\hline \multicolumn{9}{|l|}{ State Loss Ratio $\mathrm{t}_{\mathrm{t} \cdot \mathrm{J}}$} \\
\hline Stock * Log National & 0.005 & $-0.060^{\star}$ & $0.030^{\star}$ & $-0.091^{\star}$ & 0.005 & 0.016 & -0.012 & 0.017 \\
\hline Premiums Earned & $(0.032)$ & $(0.011)$ & $(0.010)$ & $(0.029)$ & $(0.010)$ & $(0.015)$ & $(0.008)$ & $(0.014)$ \\
\hline Mutual-Owned Stock * & -0.047 & -0.014 & $-0.022^{\star}$ & $0.050^{\star}$ & $0.032^{\star}$ & 0.006 & $0.023^{\star}$ & $0.057^{\star}$ \\
\hline Log National Premiums & $(0.032)$ & $(0.011)$ & $(0.010)$ & $(0.028)$ & $(0.011)$ & $(0.016)$ & $(0.009)$ & $(0.015)$ \\
\hline \multicolumn{9}{|l|}{ Earned } \\
\hline$R^{2}$ & 0.276 & 0.285 & 0.420 & 0.342 & 0.303 & 0.384 & 0.192 & 0.2229 \\
\hline
\end{tabular}

Each equation also includes a set of six dummy variables for 1986-1991 and 49 state dummy variables.

*Denotes coefficients that are statistically significant at the 95 percent confidence level, two-tailed test. 


\section{Homeowners Multipie Peril}

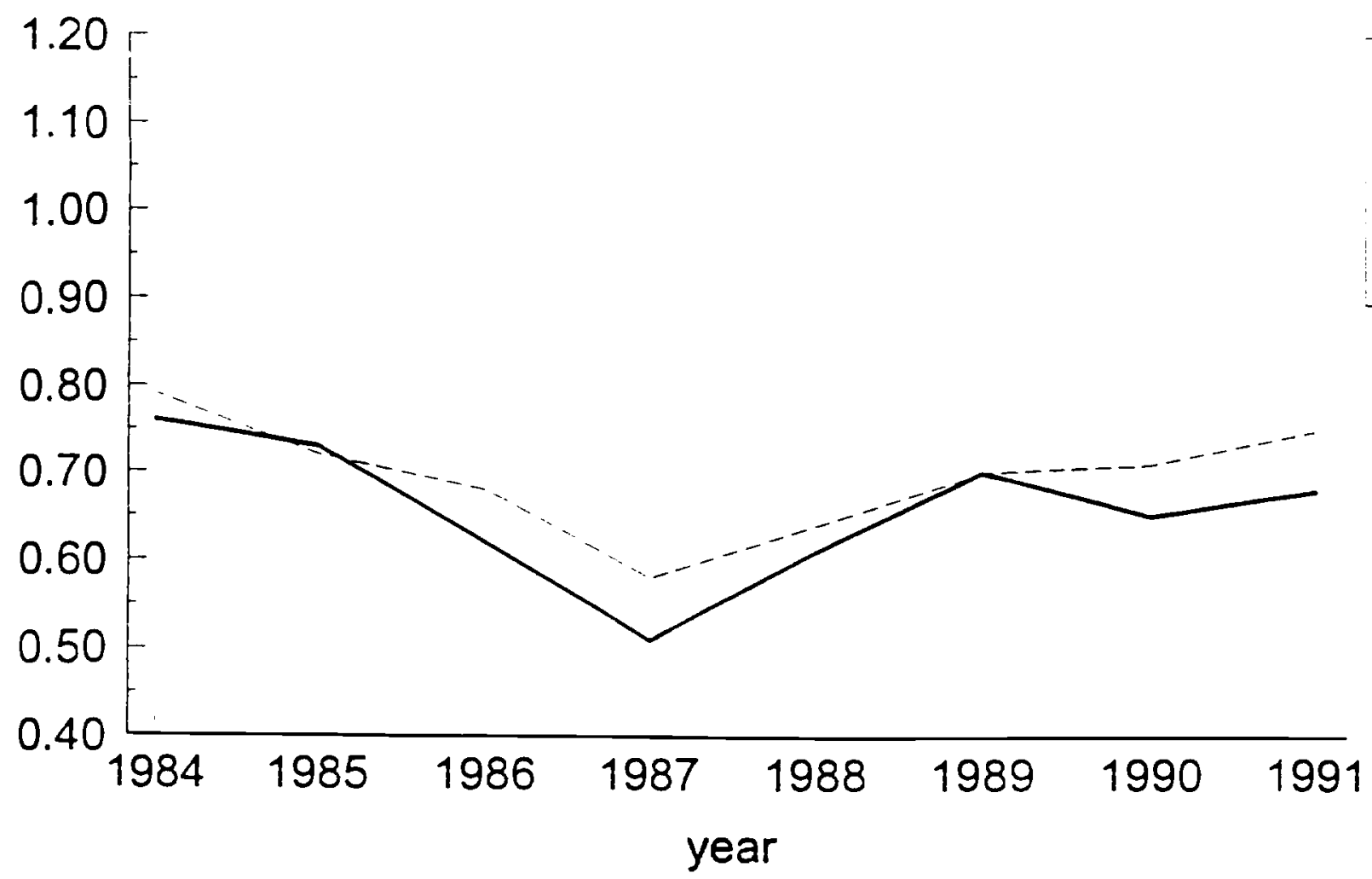

Commercial Multiple Peril

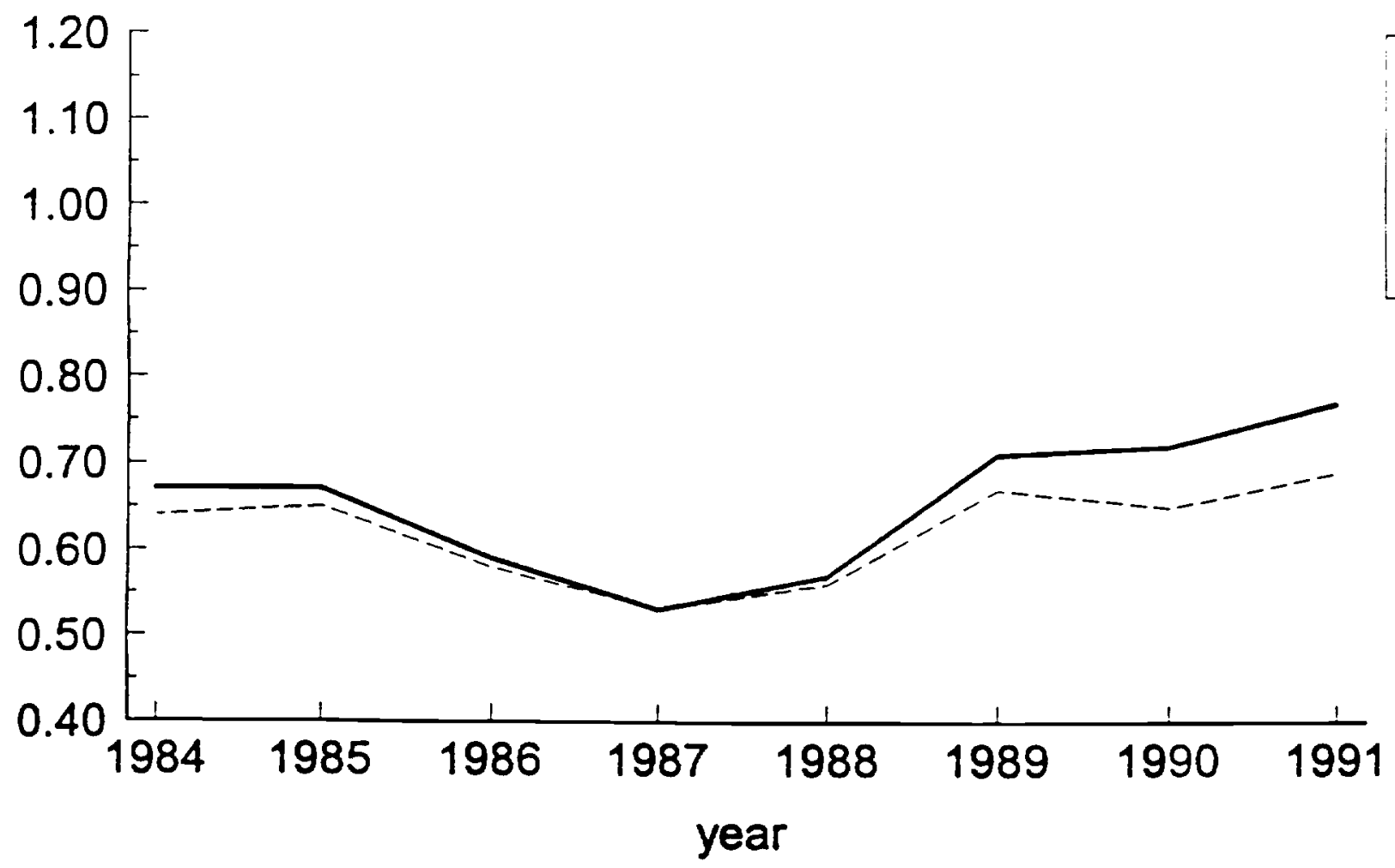

Stocks

Mutuals 
General Liabiiity

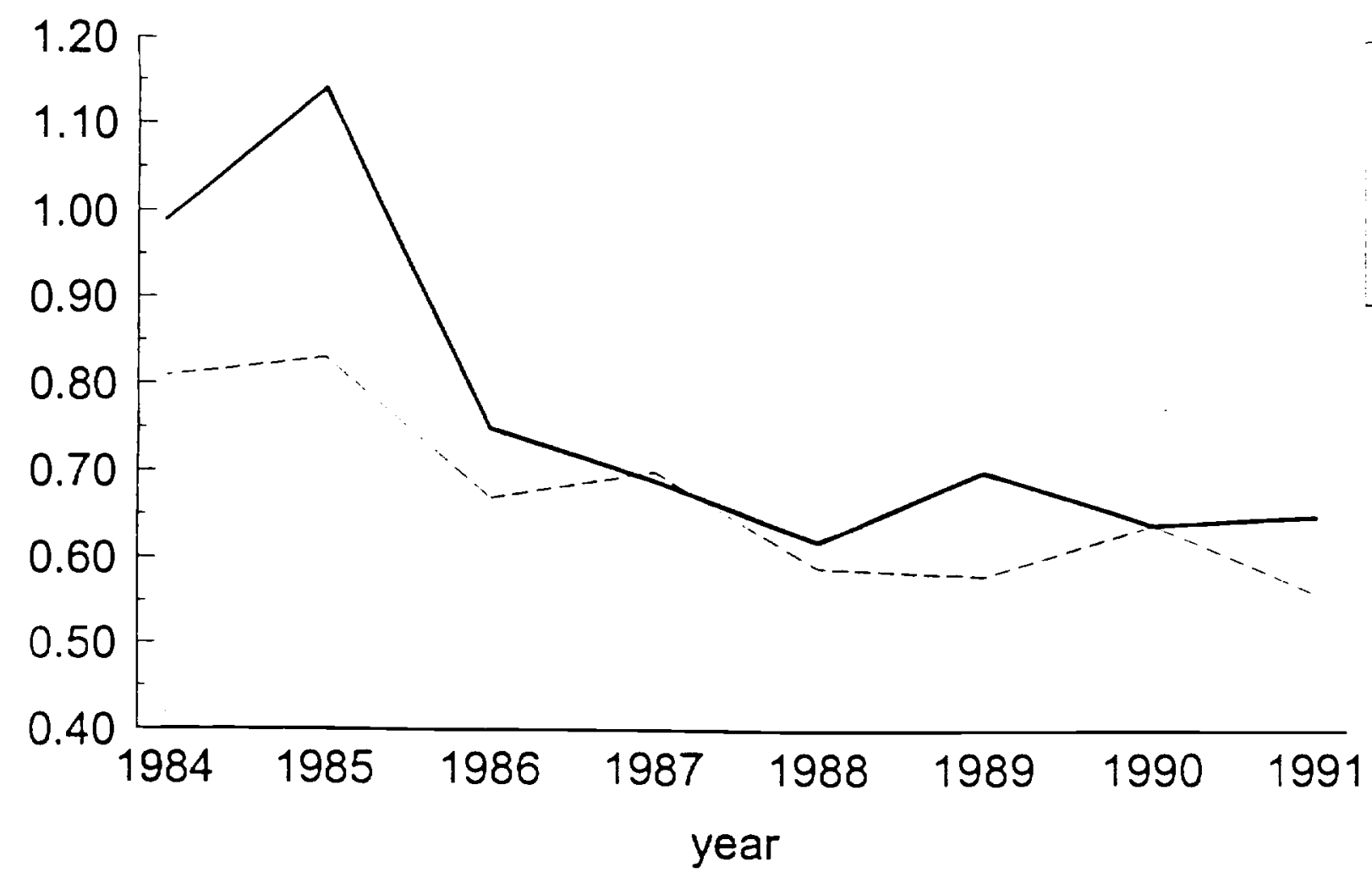

Stocks

Mutuals 

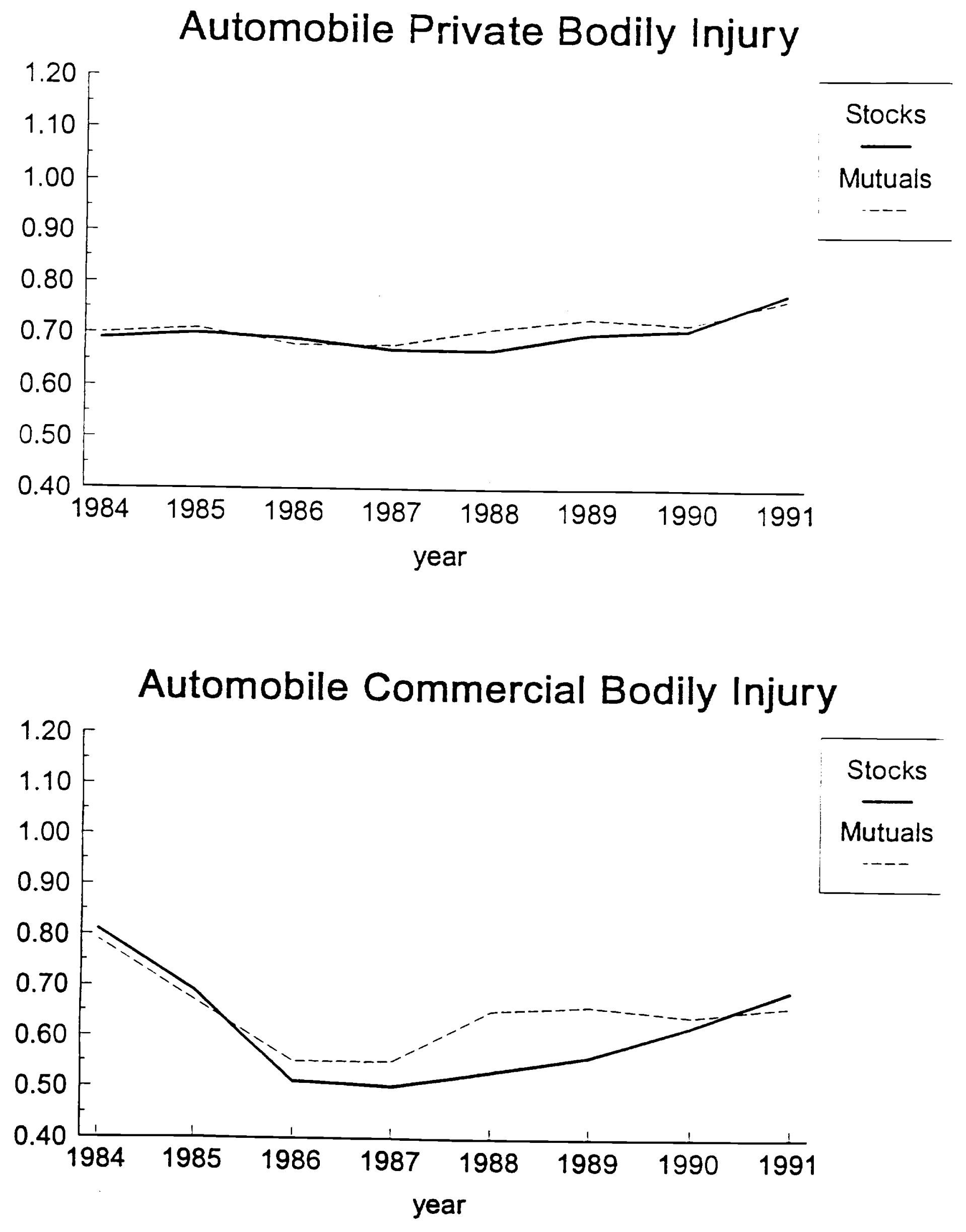


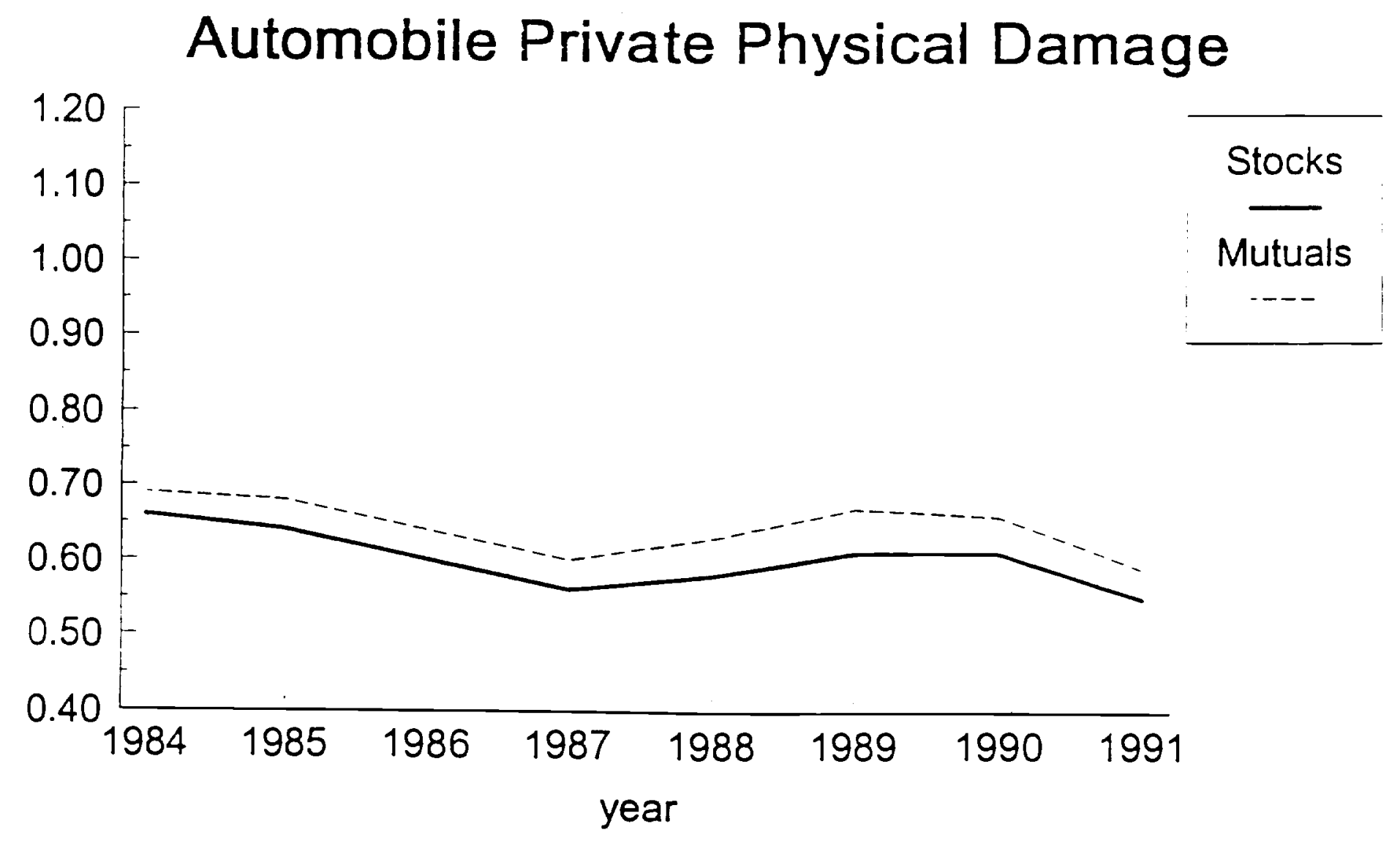

Automobile Commercial Physical Damage

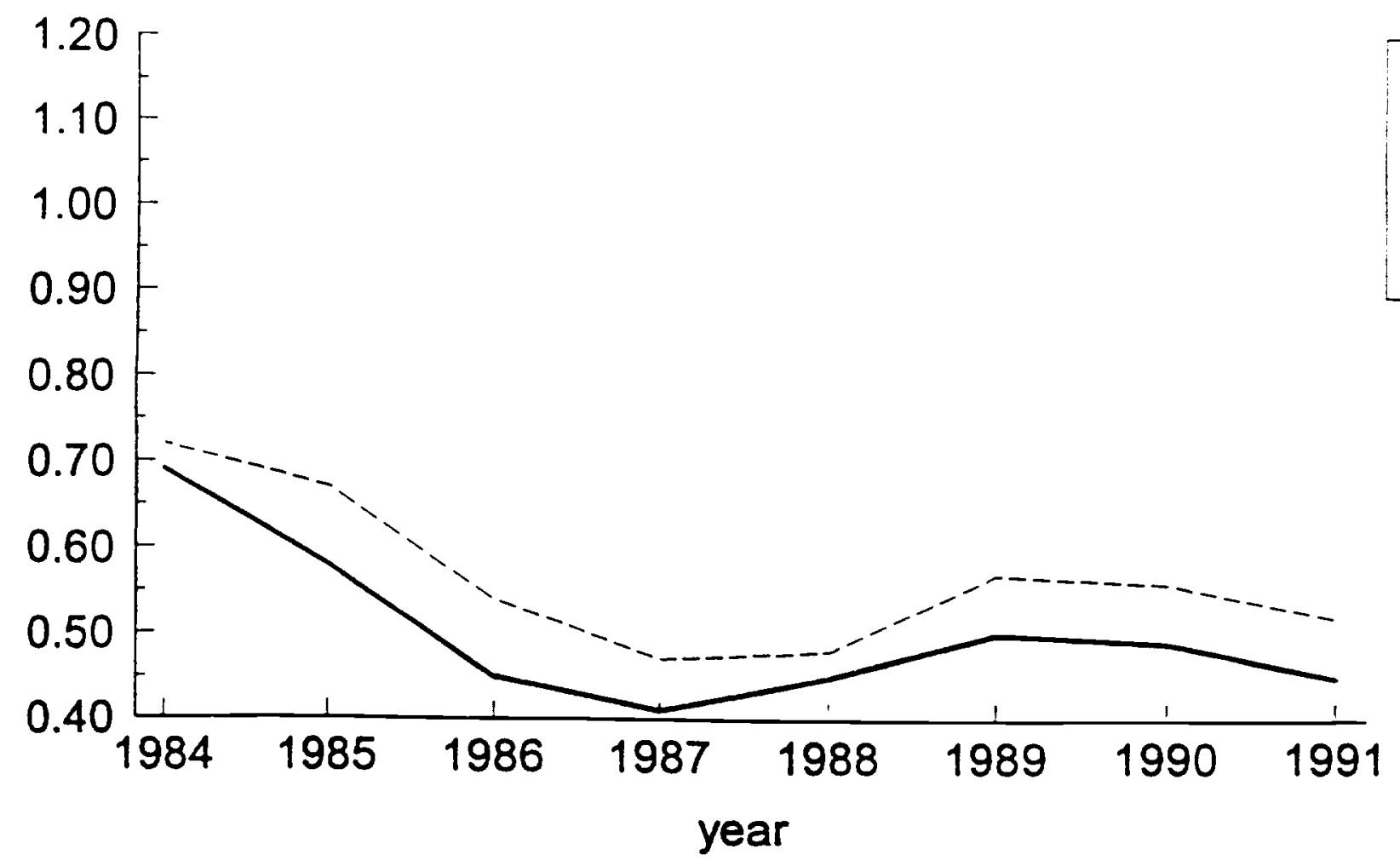

Stocks

Mutuals

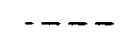

